\title{
Length-Weight Relationships and Condition Factors of Several Nigerian Fish Species
}

\author{
Timothy O. AMOO ${ }^{1 *}$, Olaniyi O. KOMOLAFE \\ ${ }^{1}$ Obafemi Awolowo University, Faculty of Science, Department ofZoology, Ile-Ife Nigeria; amootimothy@gmail.com(*orresponding author); \\ niyikomolafe2002@yahoo.co.uk
}

\begin{abstract}
The length-weight relationship and condition factor of Sarotherodon galilaeus and Oreochromis niloticus were observed in Strabag Lake, Ibadan, Nigeria. A total number of 365 individuals were caught during the period of study with Sarotherodon galilaeus constituting $65.21 \%$ of the total catch while Oreochromis niloticus made up $34.79 \%$ of the catch. The mean weight and mean total length were $56.04 \pm$ $1.019 \mathrm{~g}$ and $14.64 \pm 0.103 \mathrm{~cm}$ respectively for $S$. galilaeus, $62.86 \pm 2.184 \mathrm{~g}$ and $15.84 \pm 0.171 \mathrm{~cm}$ respectively for $O$. niloticus. The constants $a$ and $b$ of the exponential equation $W=[a L]^{b}$ were determined by transforming it into a log-transformed $\operatorname{linear}$ equation $\log W=\log a+b \log$ $L$ using the length and weight data. These parameters were then fitted to the exponential equation. The respective exponential equation for the length-weight relationship was $\mathrm{W}=0.068[\mathrm{~L}]^{2.5}$ for $S$. galilaeus and $\mathrm{W}=0.034[\mathrm{~L}]^{2.7}$ for $O$. niloticus which shows that both species exhibited negative allometric growth $(b<3.0)$. The correlation coefficient and condition factor recorded were 0.944 and 6.70 respectively for $S$. galilaeus and 0.911 and 3.49 respectively for $O$. niloticus specimens. The species showed negative allometric growth and were thriving well in the environment. However, S. galilaeus individuals were better suited to the environment than $O$. niloticus individuals $O$. niloticus individuals were thriving better in the dry season than in rainy season. Since fish cannot survive outside water, it is recommended that similar studies be carried out on the lake water to ascertain its water quality parameters status for a comprehensive management of its resources.
\end{abstract}

Keywords: allometric growth, condition factor, length-weight, O. niloticus, S. galilaeus, total length

\section{Introduction}

Fish plays an important role in the development of a nation, being a cheap source of protein and also contains other essential nutrients required by the body (Sikoki and Otobotekere, 1999). Length-weight relationships of fishes, which are crucial in the fisheries biology and assessments (Garcia et al., 1989; Haimovici and Velasco, 2000), estimate the fish's average weight with a given length category by using the mathematical relation (Beyer, 1987; Thomas et al., 2003). The values are important for estimating the number of fish at a particular time and comparison of fish species populations caught from various places at similar or different times (Thomas et al., 2003). In addition, the length-weight relationship indicates the degrees of stabilization of taxonomic characters in fish species and it is useful in the management and exploitation of fish populations (Pervin and Mortuza, 2008). Notable among the studies on length-weight relationships in fish are the reports of Shenouda et al. (1994) for Chrysichthys spp. from the Southernmost part of the River Nile (Egypt); Alfred-Ockiya and Njoku (1995) for mullet in New Calabar River; Ahmed and Saha (1996) for carps in Lake Kaptai, Bangladesh; King (1996) for Nigeria fresh water fishes; Diri (2002) for Tilapia guineensis in Elechi creek.

The relationship of length-weight estimates condition factor (K) of fish species (Wooton, 1990; Petrakis and
Stergiou, 1995; Goncalves et al., 1996; Binohlan and Pauly, 1998; Cherif et al., 2008) and fish biomass through the length frequency (Gayanilo et al., 1997; Tsoumani et al., 2006; Ayoade and Ikulala, 2007; Cherif et al., 2008). Condition factor compares the well-being of a fish and is based on the hypothesis that heavier fish of a given length are in better condition (Bagenal and Tesch, 1978). Condition factor studies take into consideration the health and general well-being of a fish as related to its environment; hence it represents how fairly deep bodied or robust fishes are (Reynold, 1968). It has been used as an index of growth and feeding intensity (Fagade, 1979). Condition factor decreases with increase in length (Bakare, 1970; Fagade 1979) and also influences the reproductive cycle in fish (Welcome, 1979). Condition factors of different species of cichlid fishes have been reported by Siddique (1977) in Lake Naivasha, Kenya; Fagade (1978, 1979, 1983) in the Lagos Lagoon, Nigeria; Dodzie and Wangila (1980) at Sagana Fish Culture Farm near Nairobi, Kenya; and Arawomo (1992) in Opa Reservoir, Ile-Ife, Nigeria. Some condition factors reported for other fish species include Hart (1997), for Mugil cephalus in Bonny estuary, Nigeria, Hart and Abowei (2007) used ten fish species from the lower Nun River, Delter, Nigeria, and Abowei and Davies (2009), Clarotes lateceps from the fresh water reaches of the lower Nun river, Delter, Nigeria. 
22

Presently, there are no reports carried out on the fish species of Strabag Lake. Therefore, this study aimed at describing the length-weight relationships and condition factors of $S$. galilaeus and $O$. niloticus which were species caught from the lake during the period of study. The growth parameters and condition factors of the fish species will provide information for management strategy of the species in Strabag Lake, Ibadan, Nigeria.

\section{Materials and Methods}

Study area

Strabag Lake is a man-made lake at Adegbayi, Ibadan, Nigeria, located between Latitude $07^{\circ} 22^{\prime} 55.80^{\prime \prime} \mathrm{N}$ and $07^{\circ} 22^{\prime} 57.96^{\prime \prime} \mathrm{N}$ and between Longitude $003^{\circ} 58^{\prime} 46.85^{\prime \prime} \mathrm{E}$ and $003^{\circ} 58^{\prime} 55.06^{\prime \prime} \mathrm{E}$ at an altitude of $220 \mathrm{~m}$ above sea level. Roughly, it assumes the shape of a trapezium with an approximated area of $0.0271 \mathrm{~km}^{2}$; it has a mean depth of $10 \mathrm{~m}$ and was a result of excavation in the early 80's (Fig. 1). Due to long residency time of water, the artificial lake now contains species of fish of unknown history. With the construction of buildings around the lake, the water body has been affected by negative anthropogenic activities.

\section{Fish sampling}

Fish samples were collected at different sampling points once a month from November 2013 to October 2014. Gill-net fishing gear, measuring $20 \mathrm{~m}$ in length and $3 \mathrm{~m}$ in depth with a mesh size of $60.35 \mathrm{~mm}$, was used to sample fish at different points on the lake (Fig. 2). Mesh sizes greater that or less than $60.35 \mathrm{~mm}$ were not effective for fish catch because no fish were caught when they were used during the preliminary study. The gill-net was set either parallel or perpendicular to the shore line. The fishes caught from each station were appropriately labelled and transported in ice-chests (for preservation) until they get to the laboratory. In the laboratory, fish species were identified using standard identification keys prepared by Paugy et al. (2003) and Adesulu and Sydenham (2007). Morphometric measurements of individual fish in the samples were taken and recorded: total length and standard length were measured with the aid of a meter rule to the nearest $0.1 \mathrm{~cm}$ while weight was determined with the aid of an electric weighing machine to the nearest $0.01 \mathrm{~g}$.
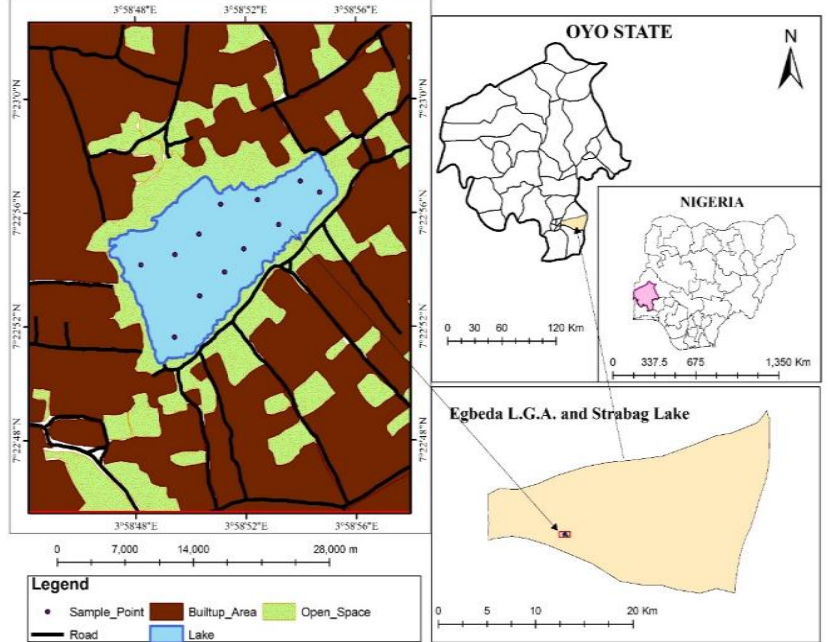

Egbeda L.G.A. and Strabag Lake

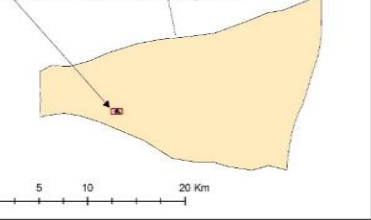

Fig. 1. Map of Nigeria showing Strabag Lake

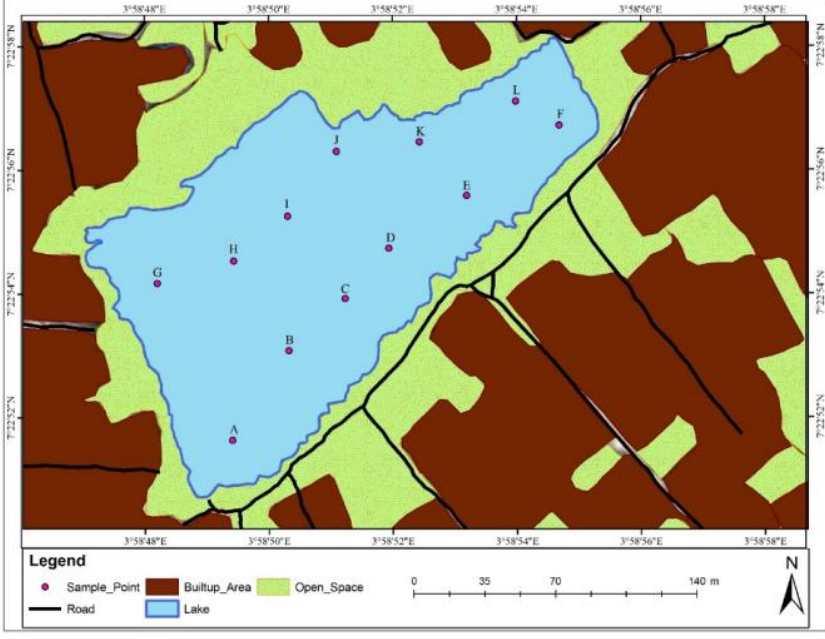

Fig. 2. Map of Strabag Lake showing sampling points

\section{Length-weight relationships (LWR)}

The relationship between the length (L) and weight (W) of fish was expressed by the equation: $W=[a L]^{b} \quad$ (Pauly, 1983), where $\mathrm{W}=$ Weight of fish in $(\mathrm{g}), \mathrm{L}=$ Total Length (TL) of fish in (cm), $\mathrm{a}=$ Constant (intercept) and $b=$ The Length exponent (slope). The "a" and " $b$ " values were obtained from a linear regression of the length and weight of fish by using their logtransformed values i.e., $\log W=\log a+b \log L$. The correlation coefficient $\left(\mathrm{r}^{2}\right)$, that is the degree of association between the length and weight was computed from the linear regression analysis.

\section{Condition factor $(K)$}

The condition factor was determined by using the equation $K=\frac{100[W]}{\left[L^{b}\right]}$ where $\mathrm{K}=$ Condition factor, $W=$ mean weight of the fish $(\mathrm{g}), L=$ mean total length of the fish $(\mathrm{cm})$ and $b=$ slope value obtained from the regression line of lengthweight equation. The exponent ' $b$ ' value, that is equal to 3 , was not used to calculate the ' $k$ ' value. Bolger and Connolly (1989) claim that it is not a real representation of the length-weight relationship for greater majority of fish species, therefore the $b$ value planned to be used if ' $b$ ' was equalled to 3 would be the one obtained from the estimated length-weight relationship equation $W=[a L]^{b}$ as suggested by Lima-Junior et al. (2002).

\section{Results}

The measurements of Length and weight in $S$. galilaeus ranged from $10.0 \mathrm{~cm}$ to $19.5 \mathrm{~cm}$ (mean $14.64 \pm 0.103$ ) and $21.75 \mathrm{~g}$ to $113.42 \mathrm{~g}$ (mean $56.04 \pm 1.019)$ respectively and from $11.8 \mathrm{~cm}$ to $22.1 \mathrm{~cm}$ (mean $16.63 \pm 0.801$ ) and $30.27 \mathrm{~g}$ to $167.75 \mathrm{~g}$ (mean $62.86 \pm 2.184$ ) respectively in $O$. niloticus (Table 1). Table 2 shows the that the size of the two species differed significantly $(\mathrm{P}<0.05)$ with $O$. niloticus individuals generally of larger size than those of $S$. galilaeus. The Logtransformed graphs of total length against weight of $S$. galilaeus and $O$. niloticus are shown in Figs. 3 and 4. The two species exhibited negative allometric growth with their bvalues less than 3 in the habitat. The respective exponential equation for the length-weight relationships were $\mathrm{W}=0.068(\mathrm{~L})^{2.5}$ 
for $S$. galilaeus and $\mathrm{W}=0.034(\mathrm{~L})^{27}$ for $O$. niloticus. The mean condition factor for $S$. galilaeus was 6.70 while it was 3.49 for $O$. niloticus.

The graphical representation of the monthly condition factors for the two species in Strabag Lake is shown in Fig. 4. The maximum and minimum condition factors for $S$. galilaeus ranged between 5.20 and 11.87 during the rainy season months of September and October. However, the maximum and the minimum condition factors $(1.26$ and 4.45$)$ for $O$. niloticus occurred in the dry and rainy months of March and October respectively. $K$ values for the species during the period of study followed approximately the same pattern. $S$. galilaeus had a significantly higher condition factor than $O$. niloticus at $\mathrm{P}<0.05$. as shown by student's T-test (table 3 ). There was a significant difference in $K$ values between the seasons in $O$. niloticus but not in $S$. galilaeus (Table 4).

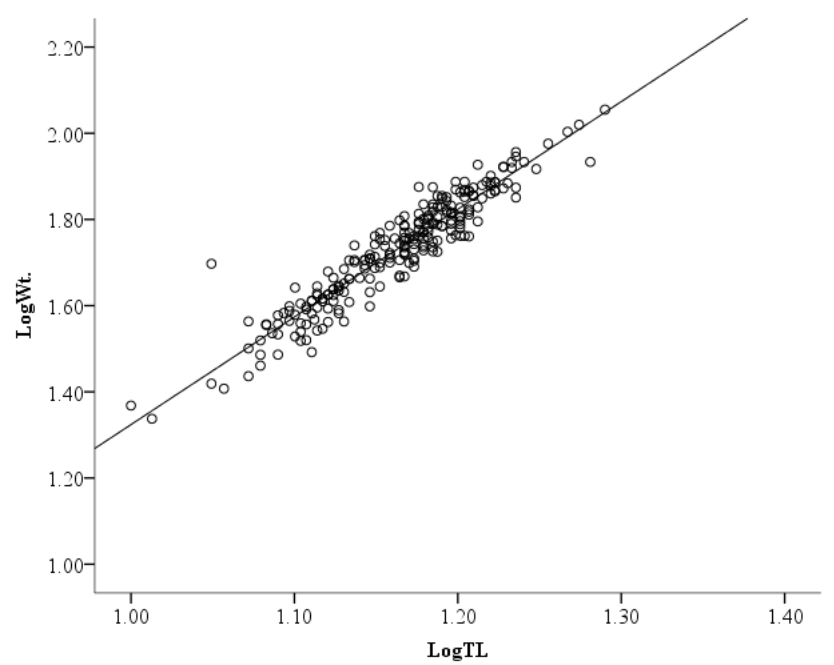

Fig. 3. Length-weight relationship of Sarotherodon galilaeus from Strabag Lake

Note: $\mathrm{Wt}=$ weight, $\mathrm{TL}=$ total length, $\mathrm{r}=$ correlation coefficient

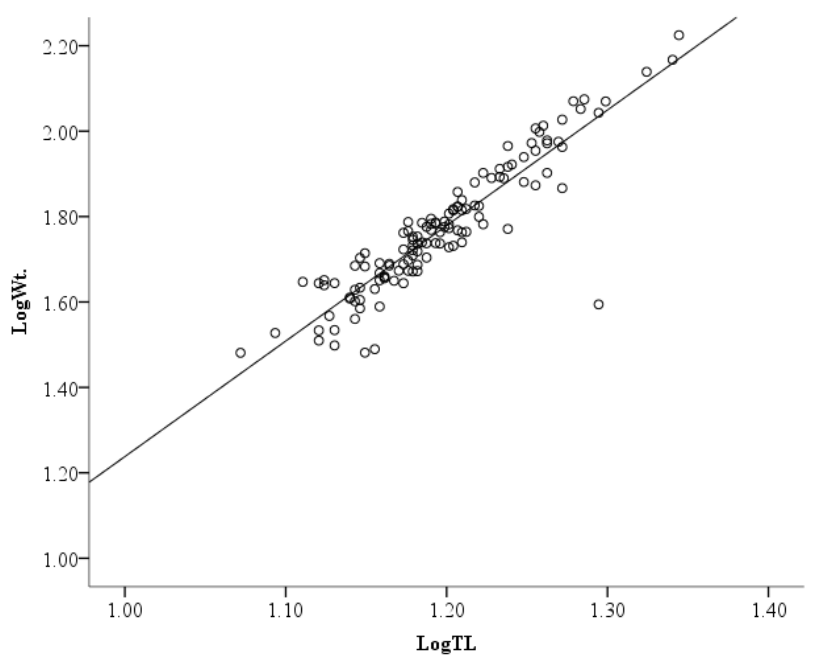

Fig. 4. Length-weight relationship of Oreochromis niloticus from Strabag Lake

Note: $\mathrm{Wt}=$ weight, $\mathrm{TL}=$ total length, $\mathrm{r}=$ correlation coefficient

\section{Discussion}

\section{Length-weight relationship}

The values obtained for the length-weight showed that $S$. galilaeus and $O$. niloticus were negatively allometric in their growth ( $b<3$ for both species). Variations growth patterns have been reported by several authors for different fish species from various water bodies. According to Pervin and Mortuza (2008) " $b$ " values usually ranged from 2.5 to 4.0 for many fish species. The above results are in agreement with the results of King (1991) who reported allometric growth patterns for Tilapia species from Umuoseriche Lake, Nigeria, and Haruna (2006) who also reported a regression coefficient of 2.7 to 3.2 for S. galilaeus from Magaga Lake, Kano, Nigeria. Benedict et al. (2009) studying sixteen fish families from Cross River inland wetlands, Nigeria, reported a regression coefficient of 2.7 each for $O$. niloticus and Heterobranchus longifilis.

The transformed length fitted over weight gave linear growth indicating the three dimensional growth structures of most fish species (Lagler et al., 1977). Values of the length exponent in the length-weight relationship being isometric implies that the fish species did not increase in weight faster than the cube of their total lengths. However, the weight of other fish species increased faster than the cube of their total lengths. Length-weight relationships give information on the condition and growth patterns of fish (Bagenal and Tesch, 1978). The regression co-efficient for isometric growth is ' 3 ' and values greater or lesser than ' 3 ' indicate allometric growth (Gayando and Pauly, 1997). As the values of " $b$ " increases, the size of the fish also increases because the fish usually grows proportionately in all directions. However, the changes in fish weight in general are actually greater than the changes in its length. The body shape of fish tends to change as the length increases. In Strabag Lake, S. galilaeus and O. niloticus showed a high correlation coefficient of $r=0.944$ and $r=0.911$ respectively indicating that the species increased in weight as the length also increased. However, there was no proportional increase in weight as the length increases since the ' $b$ ' values of both species were less than three, i.e., their growth was negatively allometric.

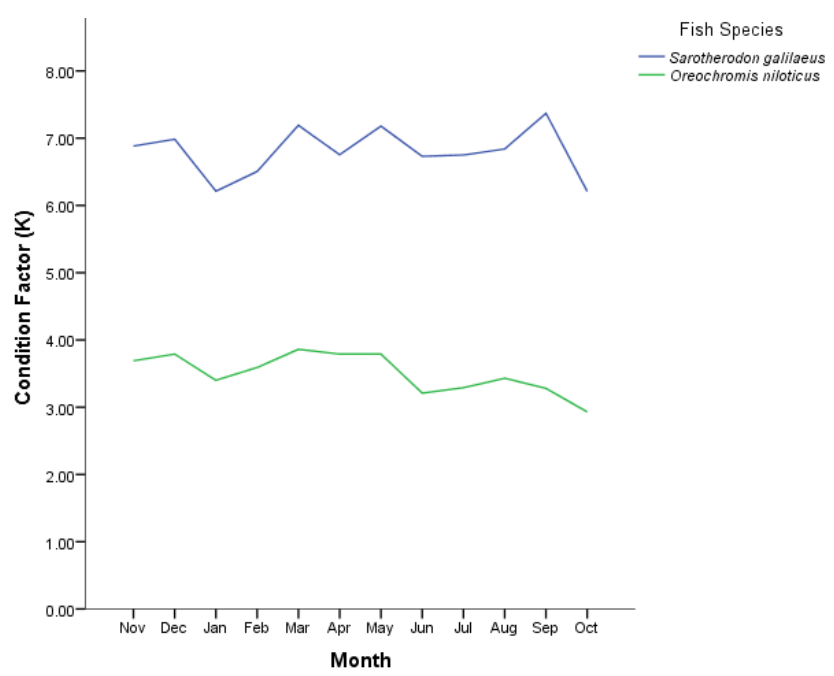

Fig. 5. Mean monthly condition factor between Sarotherodon galilaeus and Oreochromis in Strabag Lake 
Table 1.Length-weight relationship of Sarotherodon galilaeus and Oreochromis niloticus

\begin{tabular}{|c|c|c|c|c|c|c|c|c|}
\hline \multirow{2}{*}{ Fish species } & \multirow{2}{*}{$\mathrm{n}$} & \multicolumn{2}{|c|}{ Weight $(\mathrm{g})$} & \multicolumn{2}{|c|}{ Total length $(\mathrm{cm})$} & \multirow{2}{*}{$\begin{array}{c}\text { Exponetial. } \\
\text { equation }\end{array}$} & \multirow[b]{2}{*}{$\mathrm{r}$} & \multirow{2}{*}{$\mathrm{K} \pm$ S.E. } \\
\hline & & Range $(\mathrm{cm})$ & Mean \pm S.E. & Range $(\mathrm{cm})$ & Mean \pm S.E. & & & \\
\hline S. gallilaeus & 238 & $21.75-113.42$ & $56.04 \pm 1.019$ & $10.0-19.5$ & $14.64 \pm 0.103$ & $\mathrm{~W}=0.068[\mathrm{~L}]^{2.5}$ & 0.944 & $6.70 \pm 0.044$ \\
\hline O. niloticus & 127 & $30.27-167.75$ & $62.86 \pm 2.184$ & $11.8-22.1$ & $16.63 \pm 0.801$ & $\mathrm{~W}=0.034[\mathrm{~L}]^{2.7}$ & 0.911 & $3.49 \pm 0.038$ \\
\hline
\end{tabular}

Note: $\mathrm{n}=$ number of samples, $\mathrm{r}=$ correlation coefficient, $\mathrm{K}=$ condition factor, S.E. = standard error

Table 2. Student's T-test for the total length between Sarotherodon galilaeus and Oreochromis niloticus

\begin{tabular}{lccccccc}
\hline Parameter & Fish species & $\mathrm{n}$ & Range $(\mathrm{cm})$ & Mean \pm S.E. & t & df & Sig. (2-tailed) \\
\hline \multirow{2}{*}{ Total length } & S. galilaelus & 238 & $10.0-19.5$ & $14.64 \pm 0.103$ & \multirow{2}{*}{-3.320} & \multirow{2}{*}{363} & \multirow{2}{*}{$0.001^{*}$} \\
\hline *. Significant at the 0.05 level (2-tailed). & O. niloticus & 127 & $11.8-22.1$ & $16.63 \pm 0.801$ & &
\end{tabular}

Note: $\mathrm{n}=$ sample size, S.E. = standard error, $\mathrm{t}=\mathrm{T}$-test value, $\mathrm{df}=$ degree of freedom, Sig. = significance

Table 3. Student's T-test for the condition factors $(\mathrm{K})$ between Sarotherodon galilaeus and Oreochromis niloticus

\begin{tabular}{lccccccc}
\hline Parameter & Fish species & $\mathrm{n}$ & Range $(\mathrm{cm})$ & Mean \pm S.E. & $\mathrm{t}$ & $\mathrm{df}$ & Sig. (2-tailed) \\
\hline Condition & S. galilaeus & 238 & $5.20-11.87$ & $6.70 \pm 0.044$ & \multirow{2}{*}{48.531} & \multirow{2}{*}{363} & \multirow{2}{*}{$0.000^{*}$} \\
factor & O. niloticus & 127 & $1.26-4.45$ & $3.49 \pm 0.038$ & & \\
\hline${ }^{*}$ Signifina & &
\end{tabular}

${ }^{*}$. Significant at the 0.05 level (2-tailed).

Note: $\mathrm{n}=$ sample size, $\mathrm{S}$.E. $=$ standard error, $\mathrm{t}=\mathrm{T}$-test value, $\mathrm{df}=$ degree of freedom, Sig. = significance

Table 4. Student's T-test for the condition factors $(\mathrm{K})$ between the seasons

\begin{tabular}{|c|c|c|c|c|c|c|c|c|}
\hline Parameter & Fish species & Season & $\mathrm{n}$ & Range $(\mathrm{cm})$ & Mean \pm S.E. & $\mathrm{t}$ & $\mathrm{df}$ & Sig. (2-tailed) \\
\hline \multirow{4}{*}{$\begin{array}{l}\text { Condition } \\
\text { factor }\end{array}$} & S.galilaeus & Dry & 105 & $5.38-8.61$ & $6.67 \pm 0.059$ & \multirow{2}{*}{0.454} & \multirow{2}{*}{236} & \multirow{2}{*}{0.650} \\
\hline & S. galilaeus & Rainy & 133 & $5.20-11.87$ & $6.71 \pm 0.063$ & & & \\
\hline & O. niloticus & Dry & 47 & $3.00-4.15$ & $3.62 \pm 0.047$ & \multirow{2}{*}{2.557} & \multirow{2}{*}{125} & \multirow{2}{*}{$0.012^{*}$} \\
\hline & O. niloticus & Rainy & 80 & $1.26-4.45$ & $3.42 \pm 0.052$ & & & \\
\hline
\end{tabular}

*. Significant at the 0.05 level (2-tailed).

Note: $\mathrm{n}=$ sample size, $S . \mathrm{E}$. $=$ standard error, $\mathrm{t}=\mathrm{T}$-test value, $\mathrm{df}=$ degree of freedom, Sig. $=$ significance

\section{Condition factor $(K)$}

The condition factor $(\mathrm{K})$ of fish species reflects on the physiological state of the fish in relation to its welfare with respect to accumulation of fats (Le Cren, 1951), gonadal development (Angelescu et al., 1958), feeding activity (Bagenal and Tesch, 1978), density and climatic condition. The condition factor of the fish species in Strabag Lake varied from 5.20 to 11.87 with a mean value of $6.70 \pm 0.044$ for $S$. galilaeus and from 1.26 to 4.45 with mean value of $3.49 \pm 0.038$ for $O$. niloticus. Both fish species recorded high values of $\mathrm{K}$ and this shows that they were in good condition in the studied environment. However, the significant difference $(\mathrm{P}<0.05)$ in the mean condition factors of these fishes might be because the studied individuals are different species. This might also be due to the fact that $S$. galilaeus individuals were significantly larger than $O$. niloticus individuals. Fish of smaller sizes tends to have higher condition factor and hence well suited to the environment than fish of larger sizes (Bakare, 1970; Fagade 1979). According to Gayando and Pauly (1997), factors such as size classes, sex, and stages of maturity often affect fish well-being.

Vazzoler (1996) reported that condition factor can vary with gonadal development and time of year, and also among different populations. These temporal and seasonal fluctuations of the condition factor are influenced by endogenous parameters such as nutritional aspects, sex, and the state of gonadal maturation or exogenous parameters (environmental factors) affecting a population (Rodriguez, 1987). In this study, O. niloticus recorded high significant $K$ value in dry season $(3.62 \pm 0.047)$ than the rainy season $(3.42 \pm 0.052)$. This might mean a more abundant food for the species during the dry season than during the rainy season. Another explanation is that the rainy season months might be the reproductive months for $O$. niloticus in which the significant decline in condition factor is attributed to the deposition of materials for gonad formation, which may lead to increase in weight and actual spawning which lead to reduction in fish weight respectively (Mgbenka and Eyo, 1992; Vazzoler, 1996).

\section{Conclusions}

This study reveals that fish species of Strabag Lake increase in length was not proportional with the of size. The fish species were thriving well in the environment but $S$. galilaeus individuals were better suited to the environment than $O$. niloticus individuals In addition, $O$. niloticus individuals were thriving better in the dry season than in rainy season.

Since fish cannot survive outside water, it is recommended that similar studies be carried out on the lake water to ascertain its water quality parameters status for a comprehensive management of its resources.

\section{Acknowledgement}

This research received no specific grant from any funding agency in the public, commercial, or not-for-profit sectors. 


\section{References}

Abowei JFN, Davies OA (2009). Some population parameters of Clarotes laticeps (Rupell, 1829) from the fresh water reaches of the lower river, Niger Delta, Nigeria. American Journal of Scientific Research 2:15-19.

Adesulu EA, Sydenham DHJ (2007). The Freshwater Fishes and Fisheries of Nigeria. Macmillan Nigeria. Lagos, Ibadan.

Ahmed KK, Saha SB (1996). Length-weight relationship of major carps in Kaptai lake, Bangladesh. Naga ICLARM Quarterly 19(2):28.

Alfred-Ockiya JF, Njoku DC (1995). A comparative analysis of the length weight relationship and condition factors of four species of grey mullet (pisces/mugildae) from New Calabar River. Rivers State, Nigeria. Journal of Technical Education 2:5-10.

Angelescu V, Gneri FS, Nani A (1958) La merluza del mar argentino (biologia e taxonomia) [Argentina sea hake (biological taxonomy)]. Servicio de Hidrografía Naval, Secretaría de Marina 1004:1-224.

Arawomo GAA (1982). The growth of Sarotherodon niloticus. In: Proceedings of the $2^{\text {nd }}$ Annual conference of the Institute, New Bussa, Nigeria.

Ayoade AA, Ikulala AOO (2007). Length-weight relationship, condition factor and stomach contents of Hemichromis bima culatus, Sarotherodon melanotheron and Chromidotilapia guentheri (Perciformes: Cichlidae) in Eleiyele Lake, Southwestern Nigeria. Revista de Biología Tropical 55(3-4):969-977.

Bagenal TB, Tesch AT (1978). Conditions and growth patterns in fresh water habitats. Blackwell Scientific Publications, Oxford.

Bakare O (1970). Bottom deposits as food of inland fresh water fish. In: Visser SA (Ed). Kainji, a Nigerian man-made lake. Kanji Lake Studies Vol 1. Ecology Published for the Nigerian Institute.

Benedict O Offem, Yemi A Samsons, Isaac T Omoniyi (2009). Length-weight relationship, condition Factor and sex ratio of forty-six important fishes in a tropical flood river. Research Journal of Fisheries and Hydrobiology 4(2): 65-72.

Beyer JE (1987). On length-weight relationship. Part 1: Computing the mean weight of the fish of a given length class. Fishbyte 5:1113.

Binohlan C, Pauly D (1998). The length-weight table. In: Froese R Pauly D (Eds). Fishbase 1998: concepts, design and data sources. ICLARM, Manila pp 121-123.

Bolger T, Connolly PL (1989). The suitable indices for the measurement analysis of fish condition. Journal of Fish Biology. 34:171-182.

Cherif M, Zarrad R, Gharbi H, Missaoui H, Jarboui O (2008). Length-weight relationships for 11 fish species from the Gulf of Tunis (SW Mediterranean Sea, Tunisia). Pan-American Journal of Aquatic Sciences. 3(1): 1-5.

Diri MS(2002). Length -weight relationship of Sarotheredon melanotheron and Tilapia guineensis in Elechi creek Niger Delta, Nigeria. BSc Project, Rivers State University of Science and Technology, Port Harcourt.
Dodzie S, Wangila BCC (1980). Reproductive biology, length-weight relationship and relative condition of pond raised Tilapia zilli (Gervas). Journal of Fish Biology 17:243-253.

Fagade SO (1978). Age determination of Tilapia melanotheron (Ruppel) in the Lagos Lagoon, Nigeria. International Symposium on Ageing of Fish in Bagenal, Tesch.

Fagade SO (1979). Observation of the biology of two species of Tilapia from the Lagos lagoon, Nigeria. Bulletin de l'Institut Fondamental d'Afrique Noire(Ser. A) 41:627-658.

Fagade SO (1983). The biology of Chromido Tilapia guntheri from a small lake. Archiv für Hydrobiologie 97:60-72.

Garcia CB, Buarte JO, Sandoval N, Von Schiller D, Najavas P (1989). Length-weight relationships of demersal fishes from the Gulf of Salamanca. Colombia Fishbyte 21:30-32.

Gayando FC, Pauly D (1997). FAO ICLARM stock assessment tools (FISAT). References Manual, FAO Computerized Information Series (Fisheries) (8):262.

Gayanilo Jr FC, Sparre P, Pauly D (1997). The FAO-ICLARM Stock Assessment Tools (FISAT). FAO Computerised Information Series (Fisheries) No 8. Rome, FAO.

Goncalves JMS, Bentes L, Lino PG, Riberio J, Canario AVM, Erzini K (1996). Weight-length relationships for selected fish species of the small scale demersal fisheries of the south and south-west coast of Portugal. Fisheries Research 30:253-256.

Haimovici M, Velasco G (2000). Length-weight relationships of marine fishes from southern Brazil. The ICLARM Quarterly 23(1):14-16.

Hart AI, Abowei JFN (2007). A study of the length-weight relationship, condition factor and age of ten fish species from the lower Nun river. Niger Delta. African Journal of Applied Zoology and Environmental 9: 13-19.

Hart SA (1997). The biology of Mugil cephalus Linnaenus ,1758 in Bonny River Estuary. MSc Thesis. Department of Zoology, University of Port Harcourt, Nigeria.

Haruna MA (2006). Length-weight relationship of four fish species (Cichlidae) from Magaga Lake, Kano, Nigeria. Best Journal 3:109-111.

King RP (1991). The biology of tilapia mariae Bovlenger, 1899 (Perciformes: Cichlidae) in a Nigeria Rainforest stream. Ph.D. Thesis, Department of Zoology, University of Port Harcourt, Nigeria.

Lagler KF, Bardach JE, Litter RR, Passimo DRM (1977). Ichthyology. John Wiley and Sons Inc.

Le Cren ED (1951). The length-weight relationship and seasonal cycle in gonad weight and condition in the perch Perca fluviatilis. Journal of Animal Ecology 20(2):201-219.

Lima-Junior SE, Cardone IB, Goite R (2002). Determination of a method for calculation of allometric condition factor of fish. Acta Scientiarum 24:397-400.

Mgbenka BO, Eyo JE (1992). Aspects of the Biology of Clarias gariepinus Anambra River Basin 2: Maturation and condition factor. Journal of Agricultural Science and Technology 2(1) 5255. 
26

Paugy D, Leveque C, Teugels G (2003). The fresh and brackish water fishes of West Africa, Vols I and II. IRD Editions, Paris, France.

Pauly D (1983). Some simple methods for the assessment of tropical fish stocks. FAO. Fisheries Technology. Paper (234) FAO, Rome.

Pervin MR, Mortuza MG (2008). Notes on length-weight relationship and condition factor of freshwater fish, Labeo boga (Hamilton) (Cypriniformes: Cyprinidae). University Journal of Zoology. Rajshahi University 27:97-98.

Petrakis G, Stergiou KI (1995). Weight-length relationships for 33 fish species in Greek waters. Fisheries Research 21:465-469.

Reynold TD (1968). The biology of the clupeids in the New Volta. In: Man-made Lakes. The Accra Symposium. Ghana University Press, Accra.

Shenouda TS, Faten FA, Mahmoud MR, Rayzg MM (1994). A detailed study on age and growth for Chrysichthys auratus and Chrysichthys rueppelli from the southernmost part of the River Nile (Egypt). Journal of Egyptian German of Zoology 200(1412):73-101.

Siddique AQ (1977). Reproductive biology, length-weight and relative condition of Tilapia leucostica (Trewaeva in lake Naivasha, Kenya). Journal of Fish Biology 10:351-260.
Sikoki FD, Otobotekere AJT (1999). Fisheries. In: Alagoa EC (Ed). The Land People of Bayelsa State, Central Niger Delta. Port Harcourt.

Thomas J, Venu S, Kurup BM (2003). Length- weight relationship of some deep-sea fish inhabiting the continental slope beyond $250 \mathrm{~m}$ depth along the West Coast of India. NAGA, WorldFish Center Quaterly 26(2):17-21.

Tsoumani M, Liasko R, Moutsaki P, Kagalou I, Leonardos I (2006). Length-weight relationships of an invasive cyprinid fish (Carassius gibelio) from 12 Greek lakes in relation to their trophic states. Journal of Applied Ichthyology 22:281-284.

Vazzoler AEA (1996) Biologia da reprodução de peixes teleósteos: teoria e prática [reproductive biology of teleost fish: theory and practice]. Maringá: EDUEM.

Welcome RL (1979). Fisheries ecology of flood plain rivers. Longman Press, London.

Wootton JR (1990). Ecology of teleost fishes. Chapman \& Hall, London, England. 